\title{
Vinegar Production from Jabuticaba (Myrciaria jaboticaba) Fruit Using Immobilized Acetic Acid Bacteria
}

\author{
Disney Ribeiro Dias ${ }^{1 *}$, Monique Suela Silva ${ }^{2}$, Angélica Cristina de Souza ${ }^{2}$, \\ Karina Teixeira Magalhães-Guedes ${ }^{2}$, Fernanda Severo de Rezende Ribeiro ${ }^{2}$ and \\ Rosane Freitas Schwan ${ }^{2}$ \\ ${ }^{1}$ Department of Food Science, Federal University of Lavras (UFLA), University Campus, \\ 37200-000 Lavras, MG, Brazil \\ ${ }^{2}$ Department of Biology, Federal University of Lavras (UFLA), University Campus, \\ 37200-000 Lavras, MG, Brazil
}

Received: September 2, 2015 Accepted: April 13, 2016

\begin{abstract}
Summary
Cell immobilization comprises the retention of metabolically active cells inside a polymeric matrix. In this study, the production of jabuticaba (Myrciaria jaboticaba) vinegar using immobilized Acetobacter aceti and Gluconobacter oxydans cells is proposed as a new method to prevent losses of jabuticaba fruit surplus. The pulp of jabuticaba was processed and Saccharomyces cerevisiae CCMA 0200 was used to ferment the must for jabuticaba wine production. Sugars, alcohols (ethanol and glycerol) and organic acids were assayed by high-performance liquid chromatography. Volatile compounds were determined by gas chromatography-flame ionization detector. The ethanol content of the produced jabuticaba wine was approx. $74.8 \mathrm{~g} / \mathrm{L}$ ( $9.5 \%$ by volume) after $168 \mathrm{~h}$ of fermentation. Acetic acid fermentation for vinegar production was performed using a mixed culture of immobilized A. aceti CCT 0190 and G. oxydans CCMA 0350 cells. The acetic acid yield was $74.4 \%$ and productivity was $0.29 \mathrm{~g} /(\mathrm{L} \cdot \mathrm{h})$. The vinegar had particularly high concentrations of citric $(6.67 \mathrm{~g} / \mathrm{L})$, malic $(7.02 \mathrm{~g} / \mathrm{L})$ and succinic $(5.60 \mathrm{~g} / \mathrm{L})$ acids. These organic acids give a suitable taste and flavour to the vinegar. Seventeen compounds (aldehydes, higher alcohols, terpene, acetate, diether, furans, acids, ketones and ethyl esters) were identified in the jabuticaba vinegar. In conclusion, vinegar was successfully produced from jabuticaba fruits using yeast and immobilized mixed cultures of $A$. aceti and G. oxydans. To the best of our knowledge, this is the first study to use mixed culture of immobilized cells for the production of jabuticaba vinegar.
\end{abstract}

Key words: fruit vinegar, jabuticaba, alcoholic fermentation, acetic acid bacteria, immobilized cells

\section{Introduction}

The jabuticaba tree (Myrciaria jaboticaba Berg.), belonging to the family Myrtaceae, is native to Brazil. It grows spontaneously over the country, from north to south regions. The jabuticaba fruit looks like a berry, with a smooth black-purple skin when ripe. It has an average diameter of $1.9 \mathrm{~cm}$ and contains one to four seeds. The skin of the jabuticaba fruit is thin and fragile and its pulp is viscous and whitish with a sweet and slightly acid taste $(1-4)$.

The fruit's grape-like character allows its use in the production of food products such as fermented beverages, juices, jam, liqueur, and potentially, vinegar (5). M. jaboti$c a b a$ fruits are considered a natural source of functional 
antioxidant pigments (phenolic compounds) and vitamin $\mathrm{C}$ and have been used for the treatment of various diseases, including asthma, diarrhoea and hemoptysis $(6,7)$. In Brazil, the local population consumes only a small amount of this fruit because approx. 40 to $50 \%$ of the produced fruits are lost due to their short shelf life (7).

Although the number of studies on wine (8-12) and vinegar production from fruits has increased (13-18), very few studies are available on the production of jabuticaba vinegar. The industrial production of vinegar varies according to the used method, the raw materials, and the type of vinegar to be produced. Vinegar is produced by a two-step process: alcoholic fermentation of the must followed by the acetification. Starter cultures are commonly used in the food fermentation industry to predict and safeguard the product quality (19). These microbial starters have a significant role in the fermentation process (20). Yeast inoculation has been used extensively in the food industry to obtain a product with a predictable quality, including in the production of beverages such as wine $(19,21)$ and beer $(22,23)$. In contrast, the use of acetic acid bacteria $(\mathrm{AAB})$ as inoculum in the vinegar industry has traditionally been limited to the use of the mother of vinegar or back slopping. In such cases, the produced vinegar is a result of competition between microorganisms present in the base wine, particularly, wild AAB.

The taxonomy of AAB has changed significantly in the last years. Currently, apart from Acetobacter and Gluconobacter, 17 other genera are classified as AAB: Acidomonas, Ameyamaea, Asaia, Bombella, Commensalibacter, Endobacter, Gluconacetobacter, Granulibacter, Komagataeibacter, Kozakia, Neoasaia, Neokomagataea, Nguyenibacter, Saccharibacter, Swaminathania, Swingsia and Tanticharoenia (24). Different vinegars show different $\mathrm{AAB}$ profiles; nevertheless, species of the genera Acetobacter (25-28), Gluconobacter $(29,30)$ and Gluconacetobacter (31-33) (several of them have been recently renamed under the Komagataeibacter genus) (34) have been reportedly used in vinegar production.

Acetobacter aceti is a bacterium frequently used in the vinegar industry (35) because it immediately starts the fermentation process; however, when acetic acid concentrations exceed $5 \%$, other bacterial species take over the process (36). On the other hand, Gluconobacter gives a distinctive flavour to vinegar and can oxidize ethanol to acetic acid under acidic conditions (29). Thus, the use of mixed cultures ensures the best quality production of vinegar because of a rapid start and a good end to the fermentation process (36).

Cell immobilization can be defined as the physical confinement of intact cells to a defined space to preserve the metabolic or catalytic activity. Immobilization mimics the enclosure or cell aggregation that normally occurs when microorganisms grow in natural environments, with the benefit of compartmentalizing the immobilized cell. In this regard, the use of various substances as a support for cell immobilization has been studied (37-39).

In this study, a new method is developed to use and process surpluses of jabuticaba fruits in order to generate income to the post-harvest processing of jabuticaba. First, alcoholic fermentation was performed using lyophilized Saccharomyces cerevisiae CCMA 0200 cells for jabuticaba wine production, followed by vinegar production using mixed immobilized cells of $A$. aceti and G. oxydans. To the best of our knowledge, this is the first study to use Ca-alginate bead-immobilized $\mathrm{AAB}$ for the production of jabuticaba vinegar.

\section{Materials and Methods}

\section{Jabuticaba pulp processing}

Jabuticaba (Myrciaria jaboticaba Berg.) fruits were obtained from a farm in the state of Minas Gerais, southeastern Brazil. Ripe jabuticaba fruits were collected by hand from stems and branches of the jabuticaba tree and were washed with water to remove dirt. The fruit pulp was extracted by mechanical pressure and stored in polystyrene bags $(2.0 \mathrm{~L})$ at $-20^{\circ} \mathrm{C}$. The pulp samples were then characterized for total soluble solids and $\mathrm{pH}(40,41)$.

The must was prepared by defrosting the jabuticaba pulp at $22{ }^{\circ} \mathrm{C}$. The pulp had an average sugar content of 9.2 degree Brix $\left({ }^{\circ} \mathrm{Bx}\right)$ and $\mathrm{pH}=3.8$. The soluble solids were adjusted to $16^{\circ} \mathrm{Bx}$ using a sucrose solution. Dipotassium disulphite $(0.3 \mathrm{~g})$ was added to the final jabuticaba must $(3.0 \mathrm{~L})$ as an antibacterial and antioxidant agent. To improve the sedimentation of the nonfermentable solids, 1 $\mathrm{g} / \mathrm{L}$ of bentonite was added to the jabuticaba must (8).

\section{Microorganisms}

Yeast

Lyophilized Saccharomyces cerevisiae CCMA 0200 cells (Culture Collection of Agricultural Microbiology (CCMA), Federal University of Lavras, Lavras, MG, Brazil) at an initial count of $10^{7}$ cells $/ \mathrm{mL}$ were used for the production of jabuticaba wine. The yeast cells were rehydrated in sterile water at $38{ }^{\circ} \mathrm{C}$ for $30 \mathrm{~min}$ and then inoculated into the jabuticaba must for alcoholic fermentation.

\section{Acetic acid bacteria}

Vinegar was produced using a mixture of immobilized Acetobacter aceti CCT 0190 cells (André Tosello Tropical Culture Collection, Campinas, SP, Brazil) and Gluconobacter oxydans CCMA 0350 cells (CCMA).

Two culture media with different compositions were used for cell culture. The bacteria were separately cultivated in YEPD medium containing (in \%): yeast extract 1 , bacteriological peptone 2 and D-glucose 2 (HiMedia, Mumbai, India) at $30^{\circ} \mathrm{C}$ and $100 \mathrm{rpm}$ in an orbital shaker (Excella ${ }^{\circledR}$ E25; New Brunswick Scientific, Hamburg, Germany) to reach a cell count of $10^{6} \mathrm{CFU} / \mathrm{mL}$. Subsequently, the cells were transferred to YEP ethanol medium containing (in \%): yeast extract 1, bacteriological peptone 2 (HiMedia) and ethanol 6 (Synth, Diadema, Brazil) to adapt to the ethanol present in the jabuticaba wine. The cells were then incubated for $18 \mathrm{~h}$ at $30{ }^{\circ} \mathrm{C}$ and $100 \mathrm{rpm}$ in an orbital shaker and then immobilized in calcium alginate.

\section{Immobilized bacterial cells}

Bacterial cells were immobilized in calcium alginate following the method of Oliveira et al. (42), with modifications. A volume of $300 \mathrm{~mL}$ of each cell suspension (A. aceti and G. oxydans) at a count of $10^{6} \mathrm{CFU} / \mathrm{mL}$ was mixed and $6.0 \mathrm{~g}$ of sodium alginate (final mass per volume ratio of 2 $\%$ alginate; Merck, Darmstadt, Germany) were added to the mixed cell suspension. To obtain immobilized cells 
(Fig. 1), the sodium alginate cell suspension mixture was transferred to Mariotte bottles and homogenized, and beads containing the bacterial cells were prepared by dropping the suspension into a $0.1 \mathrm{M} \mathrm{CaCl}_{2}$ (Merck) solution. The prepared beads were then used as inoculum for the jabuticaba wine during acetification.

\section{Vinegar making}

\section{Alcoholic fermentation}

Fermentation was performed in a 5-litre Biostat APlus glass fermentor (Sartorius Stedim Biotech $\mathrm{GmbH}$, Goettingen, Germany) at $22{ }^{\circ} \mathrm{C}$. The must was inoculated with $10 \mathrm{~mL}$ of yeast cell suspension, corresponding to a final cell count of $10^{7}$ cells/mLin $3.0 \mathrm{~L}$ of must. Fermentation was considered finished when the sugar level $\left({ }^{\circ} \mathrm{Bx}\right)$ was stable, which was observed after $168 \mathrm{~h}$. The production of $\mathrm{CO}_{2}$ was observed during the fermentation process. Samples were taken at the beginning and the end of fermentation for microbiological and chemical analyses. At the end of fermentation, the glass fermentor was placed in an incubator (Eletrolab ${ }^{\circledR}$ EL101; Eletrolab, São Paulo, Brazil) at $10{ }^{\circ} \mathrm{C}$ to facilitate sedimentation of the solid material in the jabuticaba wine. After 10 days of incubation, the beverage was transferred to an Erlenmeyer flask to provide aeration and was incubated at $10{ }^{\circ} \mathrm{C}$ for another 30 days. After this, the jabuticaba wine was filtered through diatomaceous earth and cellulose filters under vacuum (8) and used for the production of jabuticaba vinegar during acetification.

\section{Acetic acid fermentation}

Immobilized bacterial cells ( $A$. aceti and G. oxydans) at a count of $10^{6} \mathrm{CFU} / \mathrm{mL}$ were added to $1.2 \mathrm{~L}$ of jabuticaba wine in a 2-litre Inceltech LH.SGI Discovery series 100 bioreactor (Inceltech, Toulouse, France). Approximately 10980 beads were inoculated into the bioreactor. The experiment was performed under controlled conditions at $28^{\circ} \mathrm{C}, 0.05 \mathrm{~L} / \mathrm{min}$ of oxygen and an initial $\mathrm{pH}$ of 5.0 , without stirring. Acetification was considered finished after ethanol consumption and acetic acid production were stabilized, which was observed after $264 \mathrm{~h}$. During acetification, samples were taken every $24 \mathrm{~h}$ for subsequent physical and chemical analyses.

\section{Viable cells}

The viable cells $(\mathrm{CFU} / \mathrm{mL})$ from the total number of cells of $A A B$ inside the beads were counted at time zero (when the jabuticaba wine was inoculated) and every $24 \mathrm{~h}$ until the end of vinegar production (after $264 \mathrm{~h}$ ). Ten beads (approx. $0.5 \mathrm{~mL}$ of carrier beads) were placed on a glass filter to drain the solution. The beads were then transferred to a 5-mL burette containing $3.5 \mathrm{~mL}$ of sterile distilled water. The liquid height was recorded to determine the increase in volume due to the beads. The beads were then crushed in sterilized water using a glass stick to recover the immobilized cells. The total number of $\mathrm{AAB}$ cells $(\mathrm{CFU} / \mathrm{mL})$ was determined by inoculating this cell suspension on GYC agar containing (in \%): yeast extract 1, D-glucose 10, calcium carbonate 2 and agar 2 (Merck) for $24-48 \mathrm{~h}$ at $30^{\circ} \mathrm{C}$. This culture medium is commonly used for the isolation of $\mathrm{AAB}$ because it enables the observation of the clear halo formed around their colonies after incubation (43). The differentiation of Acetobacter from Gluconobacter was done by acetate overoxidation using the chalk-ethanol test, plating samples on the Carr and Passmore medium containing (in \%): glucose 0.05 , yeast extract 0.5 , peptone 0.3 (HiMedia), calcium carbonate 1.5 , agar 1.2 and ethanol 1.5 (99.8\%; Merck) filter-sterilized and added after sterilization of the basal medium for 24$48 \mathrm{~h}$ at $30^{\circ} \mathrm{C}(44)$. The overoxidation of acetic acid by Acetobacter results in the reprecipitation of $\mathrm{CaCO}_{3}$. The clear halo was observed around the colonies of the Gluconobacter strains.

\section{Physicochemical and chromatographic analyses}

The $\mathrm{pH}$ values of the alcoholic and acetic acid fermentations were measured at room temperature using a digital pH meter (B474; Micronal, São Paulo, Brazil). The total soluble solid content was determined using a digital refractometer (PAL-1; Atago, Tokyo, Japan) and the results are expressed in ${ }^{\circ}$ Brix. The concentration of total reducing sugars was determined by the dinitrosalicylic acid (DNS) method following the method of Miller (45).

The yield was calculated as the acetic acid produced in relation to the theoretical yield. The theoretical yield was calculated by measuring the amount of ethanol con-
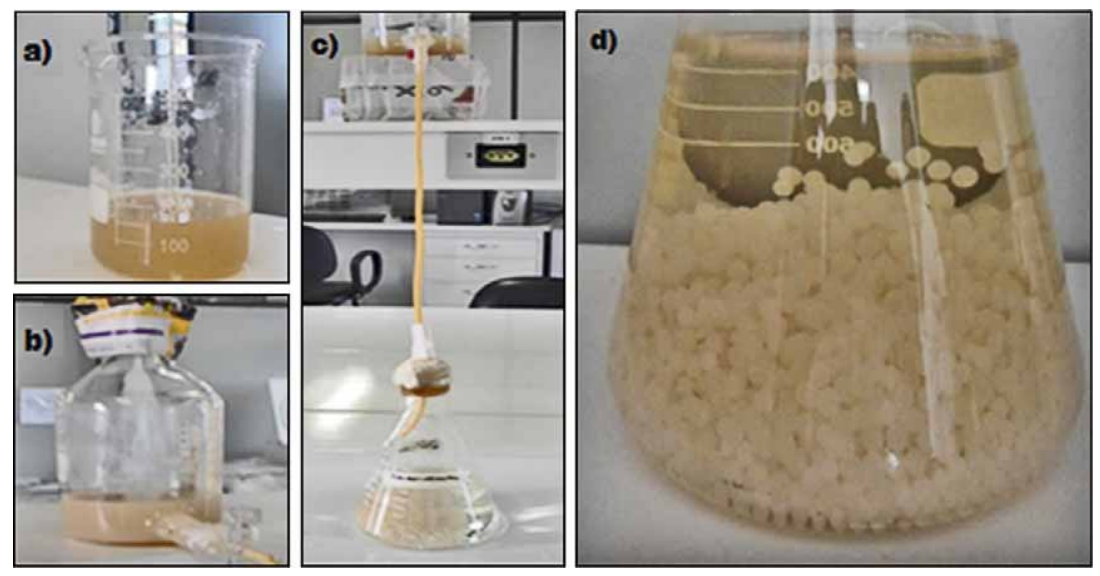

Fig. 1. Cell immobilization of acetic acid bacteria: a) hydrated sodium alginate, b) cell suspension in sodium alginate, c) immobilization system: cells suspended in the sodium alginate solution that were added dropwise to the calcium chloride solution to prepare beads, and d) prepared beads (for colour version see: www.ftb.com.hr) 
verted to acetic acid, in which $1.0 \mathrm{~g}$ of ethanol yields 1.304 $\mathrm{g}$ of acetic acid (46). Productivity was calculated from the quantity of acetic acid produced per unit of volume over time $(\mathrm{g} /(\mathrm{L} \cdot \mathrm{h}))$.

The concentration of organic acids (lactic, acetic, tartaric, malic and succinic acids), glycerol, ethanol and carbohydrates (glucose, fructose and sucrose) was measured by high-performance liquid chromatograph (LC-10AI; Shimadzu Corp., Tokyo, Japan) equipped with a refractive index detector (RID, 10A; Shimadzu) and an ultraviolet (UV) detector (SPD-10AI; Shimadzu). A cation exchange column (Shim-pack SCR-101H, $7.9 \mathrm{~mm} \times 30 \mathrm{~cm}$; Shimad$\mathrm{zu}$ ) was used at $30{ }^{\circ} \mathrm{C}$ to measure the concentration of sugars and ethanol and at $50{ }^{\circ} \mathrm{C}$ for the determination of organic acids, using $100 \mathrm{mM}$ perchloric acid as the eluent at a flow rate of $0.6 \mathrm{~mL} / \mathrm{min}$. The acids were detected by UV absorbance at $210 \mathrm{~nm}$ using a spectrophotometer (SPD-10AI; Shimadzu), whereas the sugars and ethanol were detected by RID. Individual sugars, acids and alcohols were identified by comparing their retention times with those of certified standards. Alcohols, sugars and acids were quantified by applying calibration curves obtained using standard compounds (Sigma-Aldrich, Steinheim, Germany). All samples were examined in triplicate.

Volatile compounds in the jabuticaba vinegar were analyzed directly, according to Duarte et al. (47). Analyses were performed using a gas chromatography system (GC-17A; Shimadzu) with a flame ionization detector (GC-FID). A DB Wax silica capillary column was used (30 $\mathrm{m} \times 0.25 \mu \mathrm{m} \times 0.25 \mathrm{~mm}$ i.d.; J\&W Scientific, Folsom, CA, USA). The GC-FID was operated using a gradient temperature program $\left(50{ }^{\circ} \mathrm{C}\right.$ for $5 \mathrm{~min}$, increased to $190^{\circ} \mathrm{C}$ by increments of $3{ }^{\circ} \mathrm{C} / \mathrm{min}$, and then kept at $190{ }^{\circ} \mathrm{C}$ for 10 $\mathrm{min})$. Injector and detector temperatures were kept at 240 ${ }^{\circ} \mathrm{C}$, and the carrier gas $\left(\mathrm{N}_{2}\right)$ was kept at a flow rate of 1.2 $\mathrm{mL} / \mathrm{min}$. The split mode $(1: 10)$ was defined for the $1-\mu \mathrm{L}$ sample injections. Volatile compounds were identified by comparing the retention times of the samples with those of the standards under the same conditions. The quantification of volatile compounds was expressed as 4-nonanol $(125 \mathrm{mg} / \mathrm{L})$ internal standard equivalents. To calculate the linear retention index (LRI) of each compound in the sample, a standard mixture of $n$-alkanes (C8-C40 alkanes cali- bration standard; Sigma-Aldrich, St. Louis, MO, USA) was used. One microlitre of the $n$-alkane standard was injected into the GC-FID under the same conditions as those described above and its retention times were used as an external reference for calculating the LRI of the compounds, according to van Den Dool and Kratz (48).

\section{Statistical analyses}

Each fermentation process (alcoholic and acetic acid) was conducted in duplicate and the mean values \pm standard deviations are reported. The Tukey's test using Statgraphics Plus for Windows v. 4.1 software (Statistical Graphics Corp. Rockville, MD, USA) was performed to evaluate the statistical significance $(\mathrm{p}<0.05)$.

\section{Results and Discussion}

\section{Jabuticaba wine production}

Table 1 shows the concentrations of the compounds detected in the jabuticaba wine. The concentration of ethanol increased during the fermentation of the jabuticaba must, reaching a maximum of $74.80 \mathrm{~g} / \mathrm{L}$ (9.5 \% by volume) at $168 \mathrm{~h}$ of fermentation. These results are different from those obtained by Duarte et al. (10), who reported a value of $57.0 \mathrm{~g} / \mathrm{L}$ when fermenting jabuticaba fruits (Myrciaria jaboticaba) with an initial $16^{\circ} \mathrm{Bx}$. Small concentrations of sucrose, fructose and reducing sugars were detected in the jabuticaba wine $(0.09,0.06$ and $0.04 \mathrm{~g} / \mathrm{L}$, respectively). Glucose was not detected in the jabuticaba wine (Table 1).

A rapid decrease in the sugar content and increase in the ethanol concentration $(74.80 \mathrm{~g} / \mathrm{L})$ during an inoculated fermentation was also observed by Domizio et al. (49) during the fermentation of grape must under controlled temperature conditions. This result confirmed that the selected yeast promoted a rapid increase in the concentration of ethanol. Nurgel et al. (50) found that the fermentation of nonpasteurized grapes using the selected yeast (approx. 5.0 $10^{6} \mathrm{CFU} / \mathrm{mL}$ ) was completed in 6 days, whereas indigenous fermentation lasted 10 days. These studies also reported that the $\mathrm{pH}$ values of the wines were similar (approx. 3.08).

Table 1. Physicochemical characteristics of the jabuticaba wine

\begin{tabular}{|c|c|c|c|c|c|}
\hline \multirow[t]{2}{*}{$t($ fermentation $) / \mathrm{h}$} & \multicolumn{5}{|c|}{$\gamma($ acid $) /(\mathrm{g} / \mathrm{L})$} \\
\hline & Acetic & Citric & Succinic & Malic & Oxalic \\
\hline 0 & $(0.11 \pm 0.01)^{\mathrm{a}}$ & $(1.99 \pm 0.01)^{\mathrm{a}}$ & $(0.25 \pm 0.01)^{a}$ & $(0.11 \pm 0.01)^{a}$ & $(0.09 \pm 0.01)^{a}$ \\
\hline \multirow[t]{3}{*}{168} & $(0.92 \pm 0.01)^{\mathrm{b}}$ & $(1.37 \pm 0.01)^{\mathrm{b}}$ & $(1.15 \pm 0.01)^{\mathrm{b}}$ & $(1.00 \pm 0.02)^{\mathrm{b}}$ & $(0.29 \pm 0.01)^{\mathrm{b}}$ \\
\hline & \multicolumn{4}{|c|}{$\gamma($ sugar $) /(\mathrm{g} / \mathrm{L})$} & \\
\hline & Sucrose & Glucose & Fructose & Reducing sugars & \\
\hline 0 & $(92.6 \pm 0.11)^{a}$ & $(12.60 \pm 0.08)^{a}$ & $(23.40 \pm 0.21)^{\mathrm{a}}$ & $(36.4 \pm 0.31)^{\mathrm{a}}$ & \\
\hline \multirow[t]{3}{*}{168} & $(0.09 \pm 0.01)^{\mathrm{b}}$ & n.d. & $(0.06 \pm 0.01)^{\mathrm{b}}$ & $(0.04 \pm 0.01)^{\mathrm{b}}$ & \\
\hline & \multicolumn{2}{|c|}{$\gamma($ alcohol $) /(\mathrm{g} / \mathrm{L})$} & & & \\
\hline & Ethanol & Glycerol & $\mathrm{pH}$ & $\mathrm{TTS} /{ }^{\circ} \mathrm{Bx}$ & \\
\hline 0 & n.d. & n.d. & $(3.05 \pm 0.02)^{\mathrm{a}}$ & $(15.5 \pm 0.02)^{\mathrm{a}}$ & \\
\hline 168 & $(74.80 \pm 0.41)^{\mathrm{b}}$ & $(5.10 \pm 0.01)^{\mathrm{b}}$ & $(3.02 \pm 0.02)^{\mathrm{a}}$ & $(5.37 \pm 0.02)^{\mathrm{b}}$ & \\
\hline
\end{tabular}

The data are the mean values of duplicate measurements \pm standard deviation. Different letters in the same column indicate statistically significant differences $(\mathrm{p}<0.05)$. n.d.=not detected, TTS=total soluble solids 
Lactic, tartaric, propionic and butyric acids were not detected in the jabuticaba wine. Acetic acid was formed during the fermentation of the jabuticaba must, reaching a maximum concentration of $0.92 \mathrm{~g} / \mathrm{L}$ at $168 \mathrm{~h}$ (Table 1). Acetic acid at low concentrations $(<1.0 \mathrm{~g} / \mathrm{L})$ provides a pleasant taste and inhibits the development of undesirable or pathogenic microorganisms.

Malic and citric acids were also detected in the jabuticaba wine (Table 1). The concentration of malic acid was $1.00 \mathrm{~g} / \mathrm{L}$ at $168 \mathrm{~h}$ of fermentation. During fermentation, the concentration of citric acid decreased from 1.99 (at 0 h) to $1.37 \mathrm{~g} / \mathrm{L}$ at the end of fermentation $(168 \mathrm{~h})$. It is possible that citric acid was metabolized as a carbon and energy source by $S$. cerevisiae, which has the ability to ferment or assimilate this organic acid, resulting in an increase in $\mathrm{pH}$ (51), as observed in the present study. Citric and malic acids are commonly found in fermented fruit beverages, where they act as preservatives with antimicrobial activity $(12,50)$.

Oxalic acid was detected in the jabuticaba wine before the aerobic phase of acetic fermentation (Table 1). The organic acids produced by the yeast and bacterial species contribute to the refreshing flavour, unique aroma and texture, in addition to controlling the growth of food spoilage microorganisms (10). The concentration of glycerol in the jabuticaba wine was low $(5.10 \mathrm{~g} / \mathrm{L})$. This value was consistent with that suggested by Dias et al. $(8)(<10.0$ $\mathrm{g} / \mathrm{L})$ to confer the characteristic body and texture of the beverage. Glycerol is the main secondary product of alcoholic fermentation by S. cerevisiae, which was used as the inoculum in this study. The glycerol concentration of approx. $5.1 \mathrm{~g} / \mathrm{L}$ was close to the minimum concentration of 5 $\mathrm{g} / \mathrm{L}$ in grape wine suggested by Ribéreau-Gayon et al. (52).

\section{Jabuticaba vinegar}

In the present study, a new method for vinegar production was applied using a mixture of immobilized $A$. aceti and G. oxydans cells in submerged culture fermentation in a bioreactor.

The analysis of the AAB population showed that the count of the mixed immobilized cell population was 5.2. $10^{6} \mathrm{CFU} / \mathrm{mL}$ after the end of vinegar fermentation (Fig. 2). The population of $A$. aceti was higher than that of $G$. oxydans during acetic acid fermentation. The ratio of $A$. aceti/G. oxydans population was approx. 1.20 at the end of fermentation (Fig. 2). The concentration of acetic acid in the jabuticaba vinegar reached $77.8 \mathrm{~g} / \mathrm{L}$ after $264 \mathrm{~h}$. Therefore, the mixed starter culture efficiently fermented the jabuticaba wine to produce vinegar.

The assessment of the experimental data revealed that the immobilized cell model allows an apparently proper use of the substrate and proper production of acetic acid. Encapsulation might protect the microorganism from its environment, and a link between the microbial environment and the production of acetic acid was demonstrated by the model. A slight increase in the cell density was observed during the making of jabuticaba vinegar (Fig. 2). The model system might have resulted in widespread surface growth and thus, cells were continuously released from the gel beads into the fermentation medium, leading to a decrease in the cell population in the beads (39).
However, the results showed that the release from the immobilized cell beads was negligible (data not shown).

Fig. 2 shows the ethanol consumption and acetic acid production during vinegar making. With regard to industries, the conversion of $1.0 \mathrm{~g}$ ethanol to $1.0 \mathrm{~g}$ of acetic acid can be considered economic (53). Fig. 3 shows the yield and productivity of the acetic fermentation. The production was favourable, reaching a yield of $77.4 \%$ and productivity of $0.29 \mathrm{~g} /(\mathrm{L} \cdot \mathrm{h})$. Therefore, we can conclude that the evaporation of volatile compounds was low, which might be attributed to the use of appropriate aeration $(0.05 \mathrm{~L} / \mathrm{min})$ and thermal conditions $\left(28^{\circ} \mathrm{C}\right)$.

Several organic acids in vinegar are important for imparting a suitable taste and flavour. Table 2 shows the contents of various organic acids in the jabuticaba vinegar. The total acetic acid concentration in the jabuticaba vinegar produced using a mixed culture of immobilized A. aceti and G. oxydans cells was $77.8 \mathrm{~g} / \mathrm{L}$ (Fig. 2). A similar observation had previously been made by Kocher et al. (54), who compared the production of vinegar from sugarcane juice using different inert materials for the immobilization of A. aceti cells; however, their fermentation time of 28 days was considered too long. The mixed culture of immobilized A. aceti and G. oxydans cells, an unusual condition for vinegar production, shows satisfactory

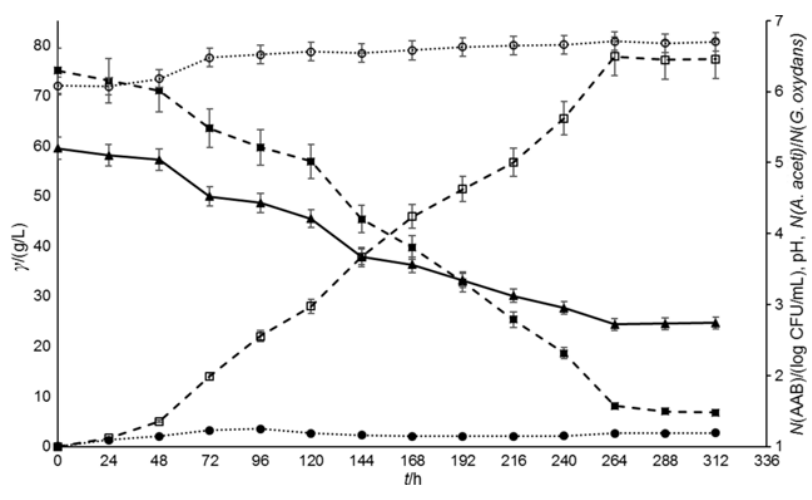

Fig. 2. Ethanol concentration (- -), acetic acid concentration $(-\square-)$, count of acetic acid bacteria $(\log \mathrm{CFU} / \mathrm{mL})(\cdots \circ \cdots), \mathrm{pH}$ value $(\multimap)$, and ratio of Acetobacter aceti/Gluconobacter oxydans counts $(\cdots \bullet \cdots)$ in the jabuticaba alcoholic must during acetic acid fermentation. The bars indicate standard deviation. $\mathrm{AAB}=$ acetic acid bacteria

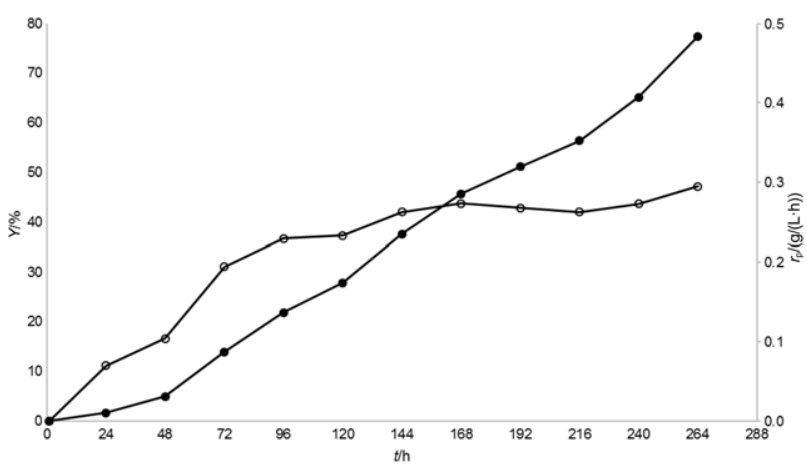

Fig. 3. Yield $(Y ; \multimap)$ and productivity $\left(r_{\mathrm{p}} ; \multimap\right)$ of acetic acid in the jabuticaba vinegar 
Table 2. Chemical characteristics of the jabuticaba vinegar

\begin{tabular}{cccccc}
\hline \multirow{2}{*}{$t$ (fermentation)/h } & \multicolumn{4}{c}{$\gamma($ acid $) /(\mathrm{g} / \mathrm{L})$} & \multicolumn{2}{c}{$\gamma($ glycerol $) /(\mathrm{g} / \mathrm{L})$} \\
\cline { 2 - 5 } & Citric & Succinic & Malic & Oxalic & $(5.32 \pm 0.01)^{\mathrm{a}}$ \\
\hline 0 & $(1.39 \pm 0.01)^{\mathrm{a}}$ & $(1.52 \pm 0.01)^{\mathrm{a}}$ & $(1.07 \pm 0.01)^{\mathrm{a}}$ & $(0.22 \pm 0.01)^{\mathrm{a}}$ & $(5.36 \pm 0.01)^{\mathrm{a}}$ \\
\hline
\end{tabular}

The data are the mean values of duplicate measurements \pm standard deviation. Different letters in the same column indicate statistically significant differences $(\mathrm{p}<0.05)$

results (i.e. the production of acetic acid along with other organic acids; Table 2) for acetic acid fermentation using jabuticaba wine. According to FAO/WHO (55), the residual ethanol content in vinegars produced by different substrates (those different from wine) must be less than $1 \%$. Further, it is recommended to have a minimum titratable acidity of $4 \%$ (56).

Table 2 shows the concentrations of citric, malic and succinic acids. The contents of these three acids increased by approx. five times compared with their initial values in the jabuticaba wine. These acids were also observed in commercial and traditional vinegars from Korea by Jang et al. (57). The lactic, tartaric, butyric and propionic acid concentrations in the jabuticaba wine were negligible and remained negligible in the vinegar. The final $\mathrm{pH}$ of the jabuticaba vinegar was 2.74 , which is attributed to the high production of acetic acid during fermentation (Fig. 2).

Seventeen compounds were identified and quantified in the jabuticaba vinegar: aldehydes, higher alcohols, terpene, acetate, diether, furans, acids, ketone and ethyl esters (Table 3, 58-61). Callejón et al. (62) identified 96 compounds in sherry vinegar: 26 esters, 23 carbonyl compounds, 20 alcohols, 14 acids, 6 volatile phenols, 3 lactones, 2 ethers, 1 acetal and 1 terpene. The flavour of vinegars is determined by a series of volatile constituents of three different origins: substrate, acetification and ageing. Although several major volatile compounds such as acetic acid, ethyl acetate and acetaldehyde contribute to the final aroma of vinegar, many other minor compounds with a wide range of polarities, solubilities and volatilities could help explain the complexity of the overall sensation, especially if the vinegar is produced from fruits $(63,64)$. Acetaldehyde $(3.72 \mathrm{mg} / \mathrm{L})$ was the only aldehyde found in the jabuticaba vinegar. It is a very volatile compound; its content tends to decrease during acetification because it is an intermediary metabolite during the conversion of ethanol to acetic acid and is thus converted to acetic acid by the same metabolic pathway (62). At low levels, acetaldehyde gives a pleasant fruity aroma to wines; however, at high concentrations, it has a pungent, irritating odour (65). Four higher alcohols were identified in the jabuticaba vinegar. Among them, 2-phenylethanol was present at high levels (Table 3). Its presence may result in flowery and sweet notes (66), which could be considered as a positive feature in the jabuticaba vinegar. Acetoin (3-hydroxy-2-butanone) was also a unique ketone that was identified in the jabuticaba vinegar (149.64 $\mathrm{mg} / \mathrm{L})$. It is a characteristic product of acetification and its concentration is very high in traditional vinegars $(64,67)$. Natera et al. (68) reported that the content of acetoin ranged from $18 \mathrm{mg} / \mathrm{L}$ in malt vinegar to $227 \mathrm{mg} / \mathrm{L}$ in apple vine-
Table 3. Concentrations of volatile compounds identified in the jabuticaba vinegar by GC-FID

\begin{tabular}{|c|c|c|c|c|}
\hline No. & Compound & LRI & $\frac{\gamma}{\mathrm{mg} / \mathrm{L}}$ & Odour quality \\
\hline & Aldehyde (1) & & & \\
\hline 1 & $\begin{array}{l}\text { Acetaldehyde } \\
\text { Higher alcohols (4) }\end{array}$ & 709 & 3.72 & Fresh, green ${ }^{a}$ \\
\hline 2 & 2-Heptanol & 1329 & 11.48 & $\begin{array}{l}\text { Coconut-like, ketonic } \\
\text { solvent-like, } \\
\text { unpleasant }^{\mathrm{b}}\end{array}$ \\
\hline 3 & 2-Methyl-1-propanol & 1079 & 7.35 & Malty $^{a}$ \\
\hline 4 & $\begin{array}{l}\text { 2-Methyl-1-butanol } \\
\text { and 3-methyl-1-butanol }\end{array}$ & 1240 & 22.21 & Malty, solvent-like ${ }^{a}$ \\
\hline 5 & $\begin{array}{l}\text { 2-Phenylethanol } \\
\text { Terpene (1) }\end{array}$ & 1896 & 31.40 & Flowery, honey-like ${ }^{a}$ \\
\hline 6 & $\alpha$-Terpineol & 1682 & 4.17 & $\begin{array}{l}\text { Pine-like, terpenoid- } \\
\text {-like }\end{array}$ \\
\hline
\end{tabular}

Acetate (1)

7 Phenylethyl acetate $1826 \quad 1.38$ Apple-like, honey-like, rosy, sweet ${ }^{\mathrm{b}}$; flowery $^{\mathrm{c}}$

Diether (1)

8 1,1-diethoxyethane $755 \quad 1.63$ n.d.

Furan (1)

9 Furfuryl alcohol $\quad 1639 \quad 14.81$ n.d. Acids (5)

10 Decanoic

2.61 Waxy, tallow, rancid, soapy $^{\mathrm{b}}$; fatty ${ }^{\mathrm{c}}$

11 Isobutyric

$1546 \quad 6.38$ Sweet, bitter $^{\text {b }}$ cheesy, rancid $^{c}$

12 Hexanoic

1.20 Fatty acid-like, vegetable oil-like cheesy, sweet ${ }^{c}$

13 Propionic

1523

2.77 Vinegar-like

14 Octanoic

2061

1.77 Fatty acid-like, vegetable oil-like ${ }^{\text {b }}$ rancid, harsh ${ }^{c}$

Ketone (1)

15 Acetoin

1309149.64 Buttery, creamy, cheesy $^{\mathrm{d}}$

Ethyl esters (2)

16 Ethyl acetate

17 Ethyl octanoate

$816 \quad 179.38$ Solvent-like, fruity

1398148.23 Apple-like, fruity ${ }^{\mathrm{b}}$; sweet $^{\mathrm{a}}$

LRI=linear retention index; ${ }^{\mathrm{a} C}$ zerny et al. (58), ' $\mathrm{b}$ Meilgaard (59), 'Siebert et al. (60), ${ }^{\mathrm{d}}$ Romano and Suzzi (61); n.d.=not determined 
gar. High concentrations of ethyl acetate and ethyl octanoate were also found in the jabuticaba vinegar $(179.38$ and $148.23 \mathrm{mg} / \mathrm{L}$, respectively; Table 3 ). The quantitatively most important volatile ester is ethyl acetate. It is present especially in vinegars produced by slow acetification processes, where high amounts of ethanol in conjunction with acetic acid are present; but in industrial vinegar, these amounts are lower. The initial ethanol content determines the formation of certain compounds such as ethyl acetate $(69,70)$. Ethyl acetate was also the major volatile compound reported by Callejón et al. (71), who described the aroma profile of different categories of sherry vinegar and reported ethyl acetate concentrations between 132 and $3955 \mathrm{mg} / \mathrm{L}$, followed by considerable concentrations of acetoin (between 194 and $1020 \mathrm{mg} / \mathrm{L}$ ) in all samples.

The results of the jabuticaba vinegar analyses show that the final product has an acceptable acetic acid mass per volume ratio of approx. $7.78 \%$ and an ethanol volume fraction lower than $1.0 \%$. Fig. 4 shows the clear appearance of the jabuticaba vinegar. The final product had a good colour (pale yellow). The vinegar had a strong flavour of jabuticaba, which compensated for the pungent smell due to volatile acids, and proved to be a very promising product.
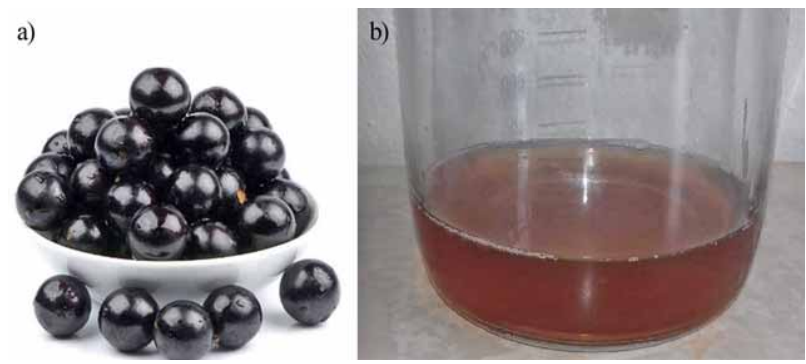

Fig. 4. The jabuticaba fruit (a) and jabuticaba vinegar (b) (for colour version see: $w w w . f t b . c o m . h r)$

\section{Conclusion}

In conclusion, vinegar was successfully produced from jabuticaba must using yeast and immobilized cells of mixed cultures of Acetobacter aceti and Gluconobacter oxydans. To the best of our knowledge, this is the first study to produce jabuticaba vinegar using mixed culture of immobilized cells. The chemical analyses revealed that the jabuticaba vinegar had a high content of organic acids and volatile compounds, which add functional value and aroma to the vinegar. The technology proposed in this study is important and proved to be a viable technique for using harvest surpluses and obtaining products with market value.

\section{Acknowledgements}

The authors thank the Coordination for the Improvement of Higher Education Personnel (CAPES - Coordenação de Aperfeiçoamento de Pessoal de Nível Superior), the National Council for Scientific and Technological Development $(\mathrm{CNPq}$ - Conselho Nacional de Desenvolvi- mento Científico e Tecnológico), and the Foundation for Research Support of the State of Minas Gerais (FAPEMIG - Fundação de Amparo à Pesquisa do Estado de Minas Gerais) for financial support and scholarships.

\section{References}

1. Andersen $\mathrm{O}$, Andersen VU. Jabuticaba. In: Andersen O, Andersen VU, editors. The Brazilian wild fruits. Rio de Janeiro, BR: Rio Gráfica Ltd; 1988. pp. 130-5 (in Portuguese).

2. Barros RS, Finger FL, Magalhães MM. Changes in non-structural carbohydrates in developing fruit of Myrciaria jaboticaba. Sci Hortic. 1996;66:209-15.

http://dx.doi.org/10.1016/S0304-4238(96)00910-7

3. Magalhãaes MM, Barros RS, Finger FL. Changes in structural carbohydrates in developing fruit of Myrciaria jaboticaba. Sci Hortic. 1996;66:17-22. http://dx.doi.org/10.1016/0304-4238(96)00911-9

4. Donadio, LC. Jaboticaba. In: Santos-Serejo JA, Dantas JLL, Sampaio CV, Coelho YS, editors. Tropical fruit crop: regional and exotic species. Brasília, DF, BR: Embrapa informação tecnológica; 2009. pp. 239-57 (in Portuguese).

5. Cavalcanti RN, Veggi PC, Meireles MAA. Supercritical fluid extraction with a modifier of antioxidante compounds from jabuticaba (Myrciaria cauliflora) byproducts: economic viability. Procedia Food Sci. 2011;1:1672-8. http://dx.doi.org/10.1016/j.profoo.2011.09.247

6. Santos DT, Meireles MAA. Jabuticaba as a source of functional pigments. Pharmacogn Rev. 2009; 3:127-32.

7. Asquieri ER, Silva AGM, Cândido MA. Jabuticaba fruit aguardiente made from skin and sediments resulting from the production of fermented jabuticaba. Food Sci Technol (Campinas). 2009;29:896-904 (in Portuguese). http://dx.doi.org/10.1590/S0101-20612009000400030

8. Dias DR, Schwan RF, Freire ES, dos Santos Serôdio R. Elaboration of a fruit wine from cocoa (Theobroma cacao L.) pulp. Int J Food Sci Technol. 2007;42:319-29. http://dx.doi.org/10.1111/j.1365-2621.2006.01226.x

9. Duarte WF, Dias DR, de Melo Pereira GV, Gervásio IM, Schwan RF. Indigenous and inoculated yeast fermentation of gabiroba (Campomanesia pubescens) pulp for fruit wine production. J Ind Microbiol Biotechnol. 2009;36:557-69. http://dx.doi.org/10.1007/s10295-009-0526-y

10. Duarte WF, Dias DR, Oliveira JM, Teixeira JA, de Almeida e Silva JB, Schwan RF. Characterization of different fruit wines made from cacao, cupuassu, gabiroba, jaboticaba and umbu. LWT - Food Sci Technol. 2010;43:1564-72. http://dx.doi.org/10.1016/j.lwt.2010.03.010

11. Duarte WF, Amorim JC, de Assis Lago L, Dias DR, Schwan RF. Optimization of fermentation conditions for production of the jabuticaba (Myrciaria cauliflora) spirit using the response surface methodology. J Food Sci. 2011;76:782-90. http://dx.doi.org/10.11811/j.1750-3841.2011.02169.x

12. Puerari $C$, Magalhães KT, Schwan RF. New cocoa pulp-based kefir beverages: microbiological, chemical composition and sensory analysis. Food Res Int. 2012;48:634-40. http://dx.doi.org/10.1016/j.foodres.2012.06.005

13. Ameyapoh Y, Leveau JY, Karou SD, Bouix M, Sossou SK, De Souza C. Vinegar production from Togolese local variety Mangovi of mango Mangifera indica Linn. (Anacardiaceae). Pak J Biol Sci. 2010;13:132-7. http://dx.doi.org/10.3923/pjbs.2010.132.137

14. Hidalgo C, Mateo E, Cerezo AB, Torija MJ, Mas A. Technological process for production of persimmon and strawberry vinegars. Int J Wine Res. 2010;2:55-61. http://dx.doi.org/10.2147/IJWR.S8741 
15. Su MS, Chien PJ. Aroma impact components of rabbiteye blueberry (Vaccinium ashei) vinegars. Food Chem. 2010;119: 923-8.

http://dx.doi.org/10.1016/j.foodchem.2009.07.053

16. Chirife J, Sansiñena M, Galmarini MV, Zamora MC. Physicochemical changes and sensory characterization of a balsamic vinegar dressing at different ${ }^{\circ}$ Brix. Food Bioprocess Technol. 2011;4:1505-11. http://dx.doi.org/10.1007/s11947-009-0235-6

17. Hidalgo C, Mateo E, Mas A, Torija MJ. Identification of yeast and acetic acid bacteria isolated from the fermentation and acetification of persimmon (Diospyros kaki). Food Microbiol. 2012;30:98-104.

http://dx.doi.org/10.1016/j.fm.2011.12.017

18. Štornik A, Skok B, Trček J. Comparison of cultivable acetic acid bacterial microbiota between organic and conventional apple cider vinegar. Food Technol Biotechnol. 2016;54:113-9. http://dx.doi.org/10.17113/ftb.54.01.16.4082

19. Ribéreau-Gayon P, Dubourdieu D, Donèche B, Lonvaud A. Cytology, taxonomy and ecology of grape and wine yeasts. In: Ribéreau-Gayon P, Dubourdieu D, Donèche B, Lonvaud A, editors. Handbook of enology. The microbiology of wine and vinifications, vol. 1. Chichester, UK: John Wiley and Sons Ltd; 2006. pp. 1-51.

20. Ayad EHE. Starter culture development for improving safety and quality of Domiati cheese. Food Microbiol. 2009;26: 533-41. http://dx.doi.org/10.1016/j.fm.2009.03.007

21. Fleet GH. Wine yeasts for the future. FEMS Yeast Res. 2008;8: 979-95. http://dx.doi.org/10.1111/j.1567-1364.2008.00427.x

22. Dufour JP, Verstrepen KJ, Derdelinckx G. Brewing yeasts. In: Boekhout T, Robert V, editors. Yeasts in food. Cambridge, UK: Woodhead Publishing Ltd; 2003. pp. 347-88. http://dx.doi.org/10.1533/9781845698485.347

23. Hutkins RW. Beer fermentation. In: Hutkins RW, editor. Microbiology and technology of fermented foods. Ames, IA, USA: Blackwell Publishing; 2006. pp. 301-47. http://dx.doi.org/10.1002/9780470277515.ch9

24. Trček J, Barja F. Updates on quick identification of acetic acid bacteria with a focus on the 16S-23S rRNA gene internal transcribed spacer and the analysis of cell proteins by MALDI-TOF mass spectrometry. Int J Food Microbiol. 2015;196: 137-44. http://dx.doi.org/10.1016/j.ijfoodmicro.2014.12.003

25. Trček J, Ramuš J, Raspor P. Phenotypic characterization and RAPD-PCR profiling of Acetobacter sp. isolated from spirit vinegar production. Food Technol Biotechnol. 1997;35:63-7.

26. Trček J, Raspor P. Molecular characterization of acetic acid bacteria isolated from spirit vinegar. Food Technol Biotechnol. 1999;37:113-6.

27. Gullo M, Caggia C, De Vero L, Giudici P. Characterization of acetic acid bacteria in 'traditional balsamic vinegar'. Int J Food Microbiol. 2006;106:209-12. http://dx.doi.org/10.1016/j.ijfoodmicro.2005.06.024

28. Yetiman AE, Kesmen Z. Identification of acetic acid bacteria in traditionally produced vinegar and mother of vinegar by using different molecular techniques. Int J Food Microbiol. 2015;204:9-16. http://dx.doi.org/10.1016/j.ijfoodmicro.2015.03.013

29. Saeki A. Application of Gluconobacter oxydans subsp. sphaericus IFO 12467 to vinegar production. J Ferment Bioeng. 1993; 75:232-4. http://dx.doi.org/10.1016/0922-338X(93)90124-Q

30. Torija MJ, Mateo E, Guillamón JM, Mas A. Identification and quantification of acetic acid bacteria in wine and vinegar by
TaqMan-MGB probes. Food Microbiol. 2010;27:257-65. http://dx.doi.org/10.1016/j.fm.2009.10.001

31. Fernández-Pérez R, Torres C, Sanz S, Ruiz-Larrea F. Strain typing of acetic acid bacteria responsible for vinegar production by the submerged elaboration method. Food Microbiol. 2010;27:273-8.

http://dx.doi.org/10.1016/j.fm.2010.05.020

32. Castro C, Cleenwerck I, Trček J, Zuluaga R, De Vos P, Caro $\mathrm{G}$, et al. Gluconacetobacter medellinensis sp. nov., celluloseand non-cellulose-producing acetic acid bacteria isolated from vinegar. Int J Syst Evol Microbiol. 2013;63:1119-25. http://dx.doi.org/10.1099/ijs.0.043414-0

33. Slapšak N, Cleenwerck I, De Vos P, Trček J. Gluconacetobacter maltaceti sp. nov., a novel vinegar producing acetic acid bacterium. Syst Appl Microbiol. 2013;36:17-21. http://dx.doi.org/10.1016/j.syapm.2012.11.001

34. Yamada Y, Yukphan P, Vu HTL, Muramatsu Y, Ochaikul D, Tanasupawat S, Nakagawa Y. Description of Komagataeibacter gen. nov., with proposals of new combinations (Acetobacteraceae). J Gen Appl Microbiol. 2012;58:397-404. http://dx.doi.org/10.2323/jgam.58.397

35. Tesfaye W, Morales ML, García-Parrilla MC, Troncoso AM. Wine vinegar: technology, authenticity and quality evaluation. Trends Food Sci Technol. 2002;13:12-21. http://dx.doi.org/10.1016/S0924-2244(02)00023-7

36. Mas A, Torija MJ, García-Parrilla MDC, Troncoso M. Acetic acid bacteria and the production and quality of wine vinegar. Sci World J. 2014;2014:1-6. http://dx.doi.org/10.1155/2014/394671

37. Kourkoutas Y, Komaitis M, Koutinas AA, Kanellaki M. Wine production using yeast immobilized on apple pieces at low and room temperatures. J Agric Food Chem. 2001;49:141725. http://dx.doi.org/10.1021/jf000942n

38. Guo X, Zhou J, Xiao D. Improved ethanol production by mixed immobilized cells of Kluyveromyces marxianus and Saccharomyces cerevisiae from cheese whey powder solution fermentation. Appl Biochem Biotechnol. 2010;160:532-8. http://dx.doi.org/10.1007/s12010-008-8412-z

39. Jalili H, Razavi H, Safari M, Amrane A. Kinetic analysis and effect of culture medium and coating materials during free and immobilized cell cultures of Bifidobacterium animalis subsp. lactis Bb 12. Electron J Biotechnol.2010;13:1-10. http://dx.doi.org/10.2225/vol13-issue3-fulltext-4

40. AOAC Official Method 932.14C. Solids (soluble) in fruits and fruit products. Rockville, MD, USA: AOAC International; 1992.

41. AOAC Official Method 960.19. $\mathrm{pH}$ of wines. Rockville, MD, USA: AOAC International; 1992.

42. Oliveira MES, Pantoja L, Duarte WF, Collela CF, Valarelli LTV, Schwan RF, Dias DR. Fruit wine produced from cagaita (Eugenia dysenterica DC) by both free and immobilized yeast cell fermentation. Food Res Int. 2011;44:2391-400. http://dx.doi.org/10.1016/j.foodres.2011.02.028

43. Mamlouk D, Gullo M. Acetic acid bacteria: physiology and carbon sources oxidation. Indian J Microbiol. 2013;53:377-84. http://dx.doi.org/10.1007/s12088-013-0414-z

44. Carr JG, Passmore SM. Methods for identifying acetic acid bacteria. In: Skinner FA, Lovelock DW, editors. Identification methods for microbiologists. London, UK: Academic Press. 1979. pp. 33-47.

45. Miller GL. Use of dinitrosalicylic acid reagent for determination of reducing sugar. Anal Biochem. 1959:31:426-8. http://dx.doi.org/10.1021/ac60147a030

46. Park YS, Ohtake H, Fukaya M, Okumura H, Kawamura Y, Toda K. Enhancement of acetic acid production in high cell- 
-density culture of Acetobacter aceti. J Ferment Bioeng. 1989; 68:315-9. http://dx.doi.org/10.1016/0922-338X(89)90004-4

47. Duarte WF, Dias DR, Oliveira JM, Vilanova M, Teixeira JA, Almeida e Silva JB, Schwan RF. Raspberry (Rubus idaeus L.) wine: yeast selection, sensory evaluation and instrumental analysis of volatile and other compounds. Food Res Int. 2010;43:2303-14.

http://dx.doi.org/10.1016/j.foodres.2010.08.003

48. van Den Dool H, Kratz PD. A generalization of the retention index system including linear temperature programmed gas-liquid partition chromatography. J Chromatogr A. 1963; 11:463-71. http://dx.doi.org/10.1016/S0021-9673(01)80947-X

49. Domizio P, Lencioni L, Ciani M, Di Blasi S, Pontremolesi C, Sabatelli MP. Spontaneous and inoculated populations dynamics and their efects on organoleptic characters of Vinsanto wine under diferent process conditions. Int J Food Microbiol. 2007;115:281-9.

http://dx.doi.org/10.1016/j.ijfoodmicro.2006.10.052

50. Nurgel C, Erten H, Canbas A, Cabaroğlu T, Selli S. Influence of Saccharomyces cerevisiae strain on fermentation and flavor compounds of white wines made cv. Emir grown in Central Anatolia, Turkey. J Ind Microbiol Biotechnol. 2002;29:2833. http://dx.doi.org/10.1038/sj.jim.7000258

51. Schwan RF, Wheals AE. The microbiology of cocoa fermentation and its role in chocolate quality. Crit Rev Food Sci Nutr. 2004;44:205-21. http://dx.doi.org/10.1080/10408690490464104

52. Ribéreau-Gayon P, Glories Y, Maujean A, Dubourdieu D. Alcohols and other volatile compounds. In: Ribéreau-Gayon $P$, Glories Y, Maujean A, Dubourdieu D, editors. Handbook of enology. The chemistry of wine and stabilization and treatments, Chichester, UK: John Wiley and Sons Ltd; 2006. pp. $51-64$. http://dx.doi.org/10.1002/0470010398.ch2

53. Maal KB, Shafiei R, Kabiri N. Production of apricot vinegar using an isolated Acetobacter strain from Iranian apricot. World Acad Sci Eng Technol. 2010;4:162-4.

54. Kocher GS, Kalra KL, Phutela RP. Comparative production of sugarcane vinegar by different immobilization techniques. J Inst Brew. 2006;112:264-6. http://dx.doi.org/10.1002/j.2050-0416.2006.tb00722.x

55. FAO Agricultural Services Bulletin No. 134. Fermented fruits and vegetables. A global perspective. Rome, Italy: Food and Agriculture Organization of the United Nations and World Health Organization (FAO/WHO); 1998. Available from: http://www.fao.org/docrep/x0560e/x0560e00.htm.

56. Compliance Policy Guides CPG, Sec. 525.825 Vinegar, definitions: adulteration with vinegar eels. Silver Spring, MD, USA: Food and Drug Administration (FDA); 2015. Available from: http://www.fda.gov/ICECI/ComplianceManuals/CompliancePolicyGuidanceManual/ucm074471.htm.

57. Jang YK, Lee MY, Kim HY, Lee S, Yeo SH, Baek SY, Lee CH. Comparison of traditional and commercial vinegars based on metabolite profiling and antioxidant activity. J Microbiol Biotechnol. 2015;25:217-26. http://dx.doi.org/10.4014/jmb.1408.08021

58. Czerny M, Christlbauer M, Fischer A, Granvogl M, Hammer M, Hartl C, et al. Re-investigation on odour thresholds of key food aroma compounds and development of an aroma language based on odour qualities of defined aqueous odorant solutions. Eur Food Res Technol. 2008;228:265-73.

http://dx.doi.org/10.1007/s00217-008-0931-x

59. Meilgaard MC. Flavor chemistry of beer: part II: flavor and threshold of 239 aroma volatiles. MBAA Techn Quart. 1975; 12:151-68.

60. Siebert TE, Smyth HE, Capone DL, Neuwöhoner C, Pardon $\mathrm{KH}$, Skouroumounis GK, et al. Stable isotope dilution analysis of wine fermentation products by HS-SPME-GC-MS. Anal Bioanal Chem. 2005;381:937-47. http://dx.doi.org/10.1007/s00216-004-2992-4

61. Romano P, Suzzi G. Origin and production of acetoin during wine yeast fermentation. Appl Environ Microbiol. 1996;62: 309-15.

62. Callejón RM, Tesfaye W, Torija MJ, Mas A, Troncoso AM, Morales ML. Volatile compounds in red wine vinegars obtained by submerged and surface acetification in different woods. Food Chem. 2009;113:1252-9. http://dx.doi.org/10.1016/j.foodchem.2008.08.027

63. Ubeda C, Callejón RM, Hidalgo C, Torija MJ, Mas A, Troncoso AM, Morales ML. Determination of major volatile compounds during the production of fruit vinegars by static headspace gas chromatography-mass spectrometry method. Food Res Int. 2011;44:259-68. http://dx.doi.org/10.1016/j.foodres.2010.10.025

64. Plessi M, Papotti G. Vinegar. In: Bamforth CW, Ward RE, editors. The Oxford handbook of food fermentations. New York, NY, USA: Oxford University Press; 2014. pp. 345-84.

65. Miyake T, Shibamoto, T. Quantitative analysis of acetaldehyde in foods and beverages. J Agric Food Chem. 1993;41: 1968-70. http://dx.doi.org/10.1021/jf00035a028

66. Perestrelo R, Fernandes A, Albuquerque FF, Marques JC, Câmara JS. Analytical characterization of the aroma of Tinta Negra Mole red wine: identification of the main odorants compounds. Anal Chim Acta. 2006;563:154-64.

http://dx.doi.org/10.1016/j.aca.2005.10.023

67. De Ley J. On the formation of acetoin by Acetobacter. J Gen Microbiol. 1959;21:352-65.

http://dx.doi.org/10.1099/00221287-21-2-352

68. Natera R, Castro R, García-Moreno MV, Hernández MJ, García-Barroso C. Chemometric studies of vinegars from different raw materials and processes of production. J Agric Food Chem. 2003;51:3345-51. http://dx.doi.org/10.1021/jf021180u

69. Morales ML, Tesfaye W, García-Parrilla C, Casas JA, Troncoso AM. Evolution of the aroma profile of sherry wine vinegars during an experimental aging in wood. J Agric Food Chem. 2002;50:3173-8 http://dx.doi.org/10.1021/jf011313w

70. Boffo EF, Tavares LA, Ferreira MMC, Ferreira AG. Classification of Brazilian vinegars according to their ${ }^{1} \mathrm{H}$ NMR spectra by pattern recognition analysis. LWT - Food Sci Technol. 2009;42:1455-60. http://dx.doi.org/10.1016/j.lwt.2009.05.008

71. Callejón RM, Morales ML, Ferreira ACS, Troncoso AM. Defining the typical aroma of sherry vinegar: sensory and chemical approach. J Agric Food Chem. 2008;56:8086-95. http://dx.doi.org/10.1021/jf800903n 